University of Nebraska - Lincoln

DigitalCommons@University of Nebraska - Lincoln

6-1-2002

\title{
Variations in character and preservation potential of vegetation- induced obstacle marks in the variable discharge Burdekin River of north Queensland, Australia
}

\author{
Katsuhiro Nakayama \\ Shimane University \\ Christopher R. Fielding \\ University of Nebraska-Lincoln, cfielding2@unl.edu \\ Jan Alexander \\ University of East Anglia
}

Follow this and additional works at: https://digitalcommons.unl.edu/geosciencefacpub

Nakayama, Katsuhiro; Fielding, Christopher R.; and Alexander, Jan, "Variations in character and preservation potential of vegetation-induced obstacle marks in the variable discharge Burdekin River of north Queensland, Australia" (2002). Papers in the Earth and Atmospheric Sciences. 385.

https://digitalcommons.unl.edu/geosciencefacpub/385

This Article is brought to you for free and open access by the Earth and Atmospheric Sciences, Department of at DigitalCommons@University of Nebraska - Lincoln. It has been accepted for inclusion in Papers in the Earth and Atmospheric Sciences by an authorized administrator of DigitalCommons@University of Nebraska - Lincoln. 
Published in Sedimentary Geology 149:4 (June 1, 2002), pp. 199-218; doi: 10.1016/S0037-0738(01)00173-7

Copyright ( 2002 Published by Elsevier Science B.V. Used by permission.

http://www.sciencedirect.com/science/journal/00370738

Submitted February 19, 2001; accepted June 29, 2001; published online May 6, 2002.

\title{
Variations in character and preservation potential of vegetation-induced obstacle marks in the variable discharge Burdekin River of north Queensland, Australia
}

\author{
Katsuhiro Nakayama, ${ }^{1}$ Christopher R. Fielding, ${ }^{2}$ and Jan Alexander ${ }^{3}$
}

1. Department of Geoscience, Faculty of Science and Engineering, Shimane University, Nishikawatsu, Matsue 690-8504, Japan

2. Department of Earth Sciences, University of Queensland, Qld 4072, Brisbane, Australia

3. School of Environmental Sciences, University of East Anglia, Norwich, NR4 7TJ, UK

Corresponding author - C. R. Fielding

\begin{abstract}
Vegetation-induced obstacle marks are described from Dalrymple Bend in the Burdekin River of Queensland, Australia, and their preservation potential is discussed. The bend is divided into a sand- and gravel-covered lower bar, and a vegetated upper bar. Obstacle marks, comprising an erosional scour and a depositional sediment tail, are recognized on the lower bar and the lower margin of the upper bar. Two types of obstacle marks are dominant in the lower part of the lower bar; sediment tail-dominated obstacle marks associated with inclined trees of Melaleuca argentea (Silverleaved Paperbark), and comparatively small obstacle marks around stranded driftwood. Obstacle marks in the upper part of the lower bar are formed around grass clumps armored with mud and gravel. At the lower margin of the upper bar, scours and gravelly sediment tails are recognized around mature tall trees. In these cases, the scour is $>4 \mathrm{~m}$ in width, and covered with alternating beds of fine sand and mud. Among the obstacle marks described, sediment tail-dominated obstacle marks around groves of $M$. argentea have the highest preservation potential. Obstacle marks in the lower margin of the upper bar are also considered to have high preservation potential. Obstacle marks around stranded driftwood have the lowest preservation potential. Obstacle marks around grass clumps survive more than 1 year, but their long-term preservation potential is nonetheless low. Implications for the stratigraphic record are also discussed.
\end{abstract}

Keywords: Obstacle marks, Fluvial systems, Vegetation, Sediment tail, Scour, Australia

\section{Introduction}

Obstacle marks are the sedimentary structures resulting from deformation of flow induced by obstacles (Dzulynski and Walton, 1965). Obstacle marks generally consist of a scour around an obstacle and a sediment tail on the lee side of the obstacle. Examples abound in most modern depositional environments such as deserts, rivers, beaches, and oceans, and are also recognized in the stratigraphic record (Allen, 1984). For example, Karcz (1968) described obstacle marks in ephemeral streams, Russell (1993) described obstacle marks around ice blocks in glacial outwash, Bhattacharya (1992) reported obstacle marks in an es- 
tuary system, and Nakayama (1992) described Cenozoic fluvial obstacle marks which were developed on the lee sides of very large boulders on a riverbed surface.

Obstacle marks formed around bridge abutments and piers have been studied for civil engineering purposes, using field measurements, flume experiments, and hydrological relationships (e.g., Jain; Melville; Lim). The relationships between scour depth, height of sediment tail, and obstacle diameter for bed features associated with vertical cylindrical obstacles in unidirectional steady flows have been clarified (e.g., Larras; Breusers; Shen). Karcz (1968) and Allen (1984) explain the processes forming these obstacle marks. According to their explanations, obstacles fixed within a flow bottom such as a riverbed divert the flow, and produce secondary flow and localized flow acceleration. This increases bed shear stress up to 12 times that of undistributed flow (Carstens and Sharma, 1975). Enhanced velocities immediately in front of and to the sides of an obstacle prevent the deposition of sediment and scour the bed. Flow separation in the lee of an obstacle produces an area of reduced bed shear stress and a site for potential sediment accumulation.

Unlike engineered structures, trees, driftwood and other natural obstacles rarely approximate to vertical cylinders, and the flow patterns and resulting bed morphologies are more complex. Woodyer et al. (1979), Wende and Nanson (1998), and Gibling et al. (1998) documented the interaction between vegetation and fluvial flow in Australia. McKee et al. (1967), Jackson (1976), Nanson (1981), and Harwood and Brown (1993) highlighted in-channel vegetation and its importance for bar growth. However, descriptions of obstacle marks around natural obstacles such as in situ trees and driftwood are still lacking from the literature. It is important for geomorphologists, geologists and civil engineers to elucidate the relationships between obstacles, scours, sediment tails, geographical setting, and hydrology in modern fluvial systems. Such studies enable the quantitative and qualitative analysis of obstacle marks in the stratigraphic record. The relationship between natural obstacle shape and the obstacle mark size provides constructive information for the design of artificial obstacles. The ideal fluvial system for such a study should have highly variable discharge, obvious topographical features, and long hydrological records.
The Burdekin River in north Queensland, Australia, is a tropical fluvial system which experiences two to four orders of magnitude variation in discharge, in response to seasonal rainfall. Hydrological records have been kept for more than 70 years by Queensland Department of Natural Resources (Water Resources Commission). Recently, significant research effort has been devoted to the sedimentology and geomorphology of the upper Burdekin River. Fielding and Alexander (1996) and Alexander and Fielding (1997) described geomorphological features and bedforms on the riverbed, Alexander et al. (1999b) summarized hydrological characteristics including flood behavior, and Fielding et al. (1999) demonstrated the internal structure of bar deposits and their reworking potential on the basis of ground-penetrating radar (GPR) surveys. Additionally, Fielding et al. (1997) and Alexander et al. (1999a) clarified the in situ plant strategy for adaptation to variable discharge flow and the processes that lead to accumulation of plant fragments. The Burdekin River is an ideal modern fluvial system for obstacle mark research.

This paper describes obstacle marks around in situ trees and grasses, and stranded driftwood observed on Dalrymple Bend in the upper Burdekin River (Figure 1), interprets the formative processes, and discusses the long-term preservation potential of each type of obstacle mark. This paper offers criteria to assist in the interpretation of obstacle marks in the coarse-grained fluvial components of the stratigraphic record.

Although this field area has been observed since 1993, this paper mainly presents observations made at low-flow stage in September 2000. Surface features such as sediment type, bedforms, vegetation characteristics, and obstacle marks (morphology and orientation of obstacles and obstacle marks) were recorded in detail over an area of $6 \times 10^{5} \mathrm{~m}^{2}$. Description was performed mainly along seven transverses, five of which were roughly transverse to mean flow direction, and two roughly parallel to flow direction. Each location was measured by GPS (Casio PRT-1), associated with electronic compass (Casio PRT-411) and range meter (Bushnell Yardage Pro1000). Described features were mapped on to aerial photographs and topographic maps generated from our survey data. Data collected in 2000 were compared with data from previous years. Although the surface distribution of bedforms and other fea- 


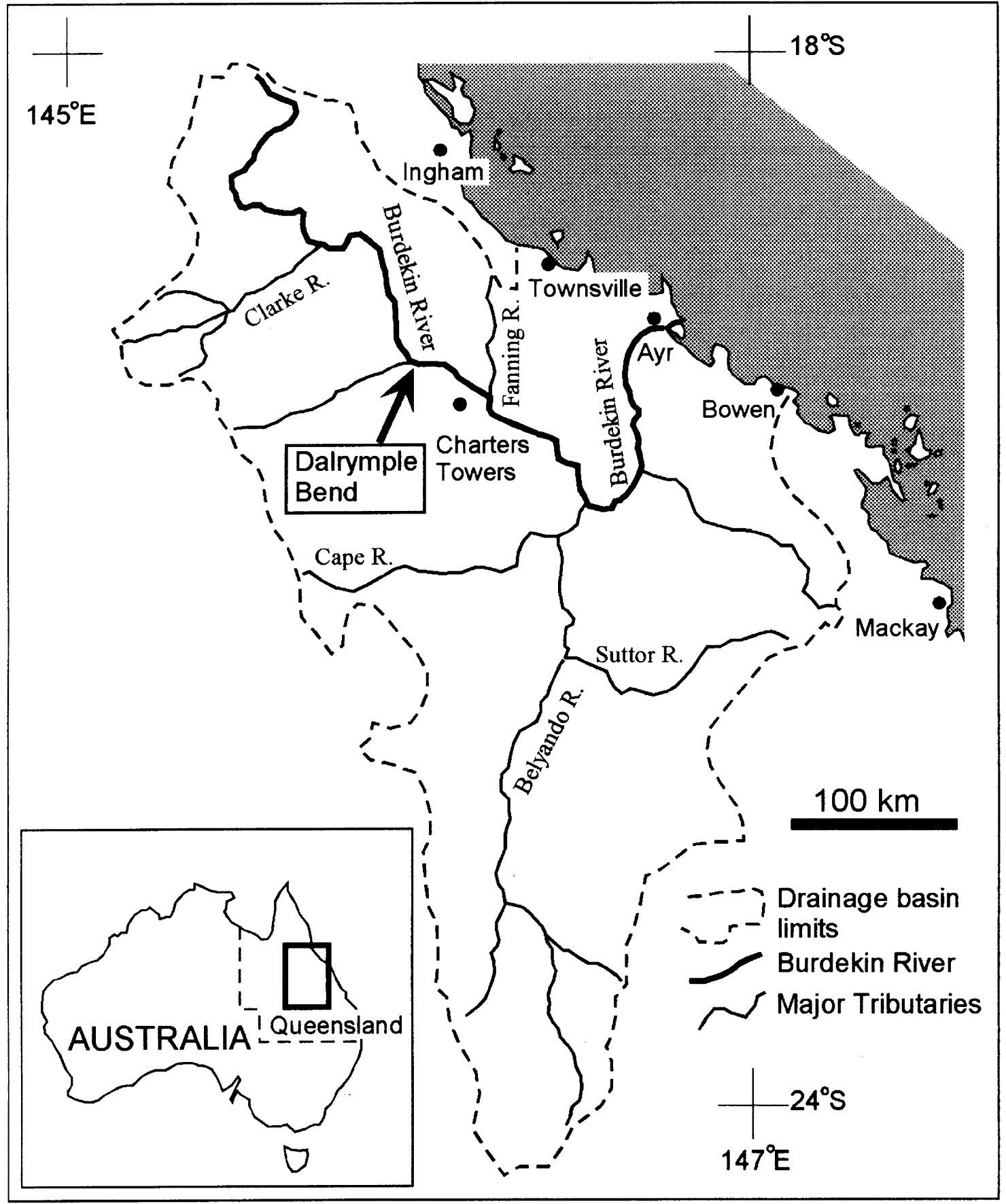

Figure 1. Map showing the location of the study area (Dalrymple Bend) and the Burdekin River drainage basin in north Queensland, Australia.

tures varies from year to year, a general pattern has been recognized.

\section{Burdekin River, and Dalrymple Bend}

The Burdekin River has the largest mean annual runoff of any river on the east coast of tropi- cal Queensland and drains $129,500 \mathrm{~km}^{2}$. For up to 11 months of the year, much of the riverbed is dry, with a narrow "misfit" perennial channel carrying a modest flow $\left(0-20 \mathrm{~m}^{3} \mathrm{~s}^{-1}\right)$. In the summer wet season, intense rainfall associated with tropical cyclones may cause river levels to rise rapidly, often two to four orders of magnitude within $24 \mathrm{~h}$. High discharge is maintained for a few hours to a few days and flow 
recedes exponentially (Fielding and Alexander, 1996). Monsoon trough activity over the catchment in some years (as in 2000) produces more gradual rise and fall of stage over a period of weeks. Discharge over 25,600 $\mathrm{m}^{3} \mathrm{~s}^{-1}$ was recorded in 1927 near Charters Towers (Figure 1) $35 \mathrm{~km}$ downstream of the study site. Flood-wave speed in the middle and upper parts of the river is estimated as $2.4-4 \mathrm{~m} \mathrm{~s}^{-1}$ (Alexander et al., 1999b). The number of flow events varies from year to year, and smaller flows occur in most years. Almost all such events are limited to January, February, and March.

The modern, upper Burdekin River varies from straight to moderately sinuous ( 1.3). Around the study area, the river has a mean gradient of 0.00058 (Burdekin Project Committee, 1977). The channel bed is generally $300-400 \mathrm{~m}$ wide and width/depth ratio varies between 10 and 30 . The channel is typically incised between 5 and $25 \mathrm{~m}$ into its own alluvium, or locally into Cenozoic basalt and Paleozoic bedrock.

Dalrymple Bend (Figure 1) is coincident with the confluence of Keelbottom Creek (Figure 2). The bend has the surface form of a point bar, with the perennial (low-stage) stream situated close to the outer bank. The low-stage stream is $50-100 \mathrm{~cm}$ deep, and $50-100 \mathrm{~m}$ wide for most of the year. Several (flat-topped) transverse bars are recognized on the channel floor, scaled to the low-stage flow. A gently sloping sand- and gravel-covered lower bar rises to a vegetated upper bar. The upper bar passes inward into a succession of ridges and swales with an amplitude of approximately $5 \mathrm{~m}$ and a wavelength of 100 to $150 \mathrm{~m}$. The lower bar is topographically subdivided into a lower part (0-3 $\mathrm{m}$ above the channel bottom), and an upper part (3-6 $\mathrm{m}$ above channel bottom). The upper and lower parts of the lower bar are separated from each other by a steep face (avalanche slope) around the middle and downstream parts of the bend. The base of the steep face is $3-5 \mathrm{~m}$ above the channel bottom. The avalanche slope, shown as the boundary in Figure 2, is formed by erosion during intermediate-stage flow or waning stage of bankfull flow (cf. Fielding et al., 1999). This complex bar is similar in form to others along the Burdekin River. The geomorphology of the Dalrymple Bend, however, is locally complicated by the confluence of Keelbottom Creek and by areas of bedrock exposure both at the northern entrance and southern exit of the bend. The distinction between the lower and the upper parts of the lower bar is ambiguous around the northern entrance of the bend, due to the presence of left scrolled sediment sheets $0.5-1.5 \mathrm{~m}$ thick and 100-300 $\mathrm{m}$ long (see bedform orientations in Figure 2), anchored to the bedrock exposure at the bend entrance. Obstacle marks are abundant on the lower bar and the lower margin of the upper bar.

The lower part of the lower bar surface is dominated by gently sloping plane beds and (washedout) dunes, sometimes (in some years) associated with gravelly antidunes (cf. Alexander and Fielding, 1997) and mud film cover. Grain-size of surface sediment ranges mainly between very coarse sand and pebbles, locally with medium sand reworked into wind ripples. Little vegetation is present on the lower bar, but linear groves of Melaleuca argentea trees occur at the entrance and exit of the bend and near the confluence point of Keelbottom Creek. At the confluence point, linear groves of $M$. argentea are associated with vegetated transverse bars (Figure 3) on which grass has grown. Obstacle marks in the lower part of the lower bar are formed around these groves, and stranded driftwood. Strictly speaking, the low-stage transverse bars may be distinct from the lower bar. However, the transverse bars frequently merge topographically with the lower bar during the dry season. We deal with these transverse bars as a part of the lower bar.

The upper part of the lower bar is a comparatively flatter surface that is about 5-6 $\mathrm{m}$ above the channel bottom. Surface grains predominantly vary between very coarse sand and pebbles, and form dunes. Gravel patches (up to cobble grade) are common. Alternating beds of medium sand and sandy mud 5-25 mm thick are frequently observed in the bar subsurface, but muddy material on the surface is restricted to the bend entrance. Vegetation on the upper part of the lower bar is sporadically distributed monocotyledon grass clumps. At present, there are no in situ trees on this part of the bend. Obstacle marks on this surface form around grass clumps and stranded driftwood. There are substantially fewer stranded driftwood fragments on the upper part than on the lower part of the lower bar, and those fragments that were observed were generally smaller.

The upper bar is covered with dense grass vegetation and trees such as Eucalyptus camaldulensis (River 


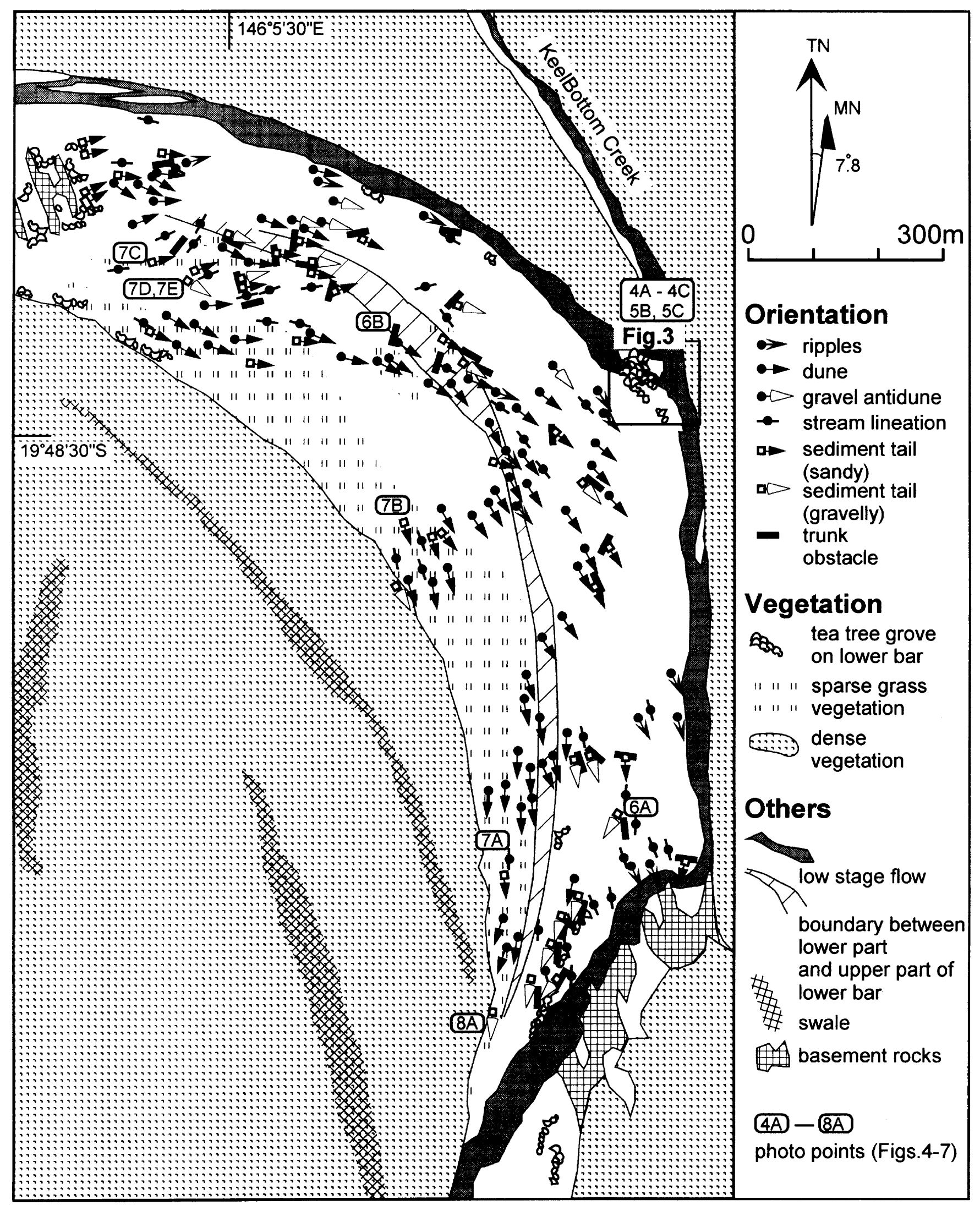

Figure 2. Morphological and sedimentological features of Dalrymple Bend. The dense vegetation area on the right bank side coincides with the upper bar. 


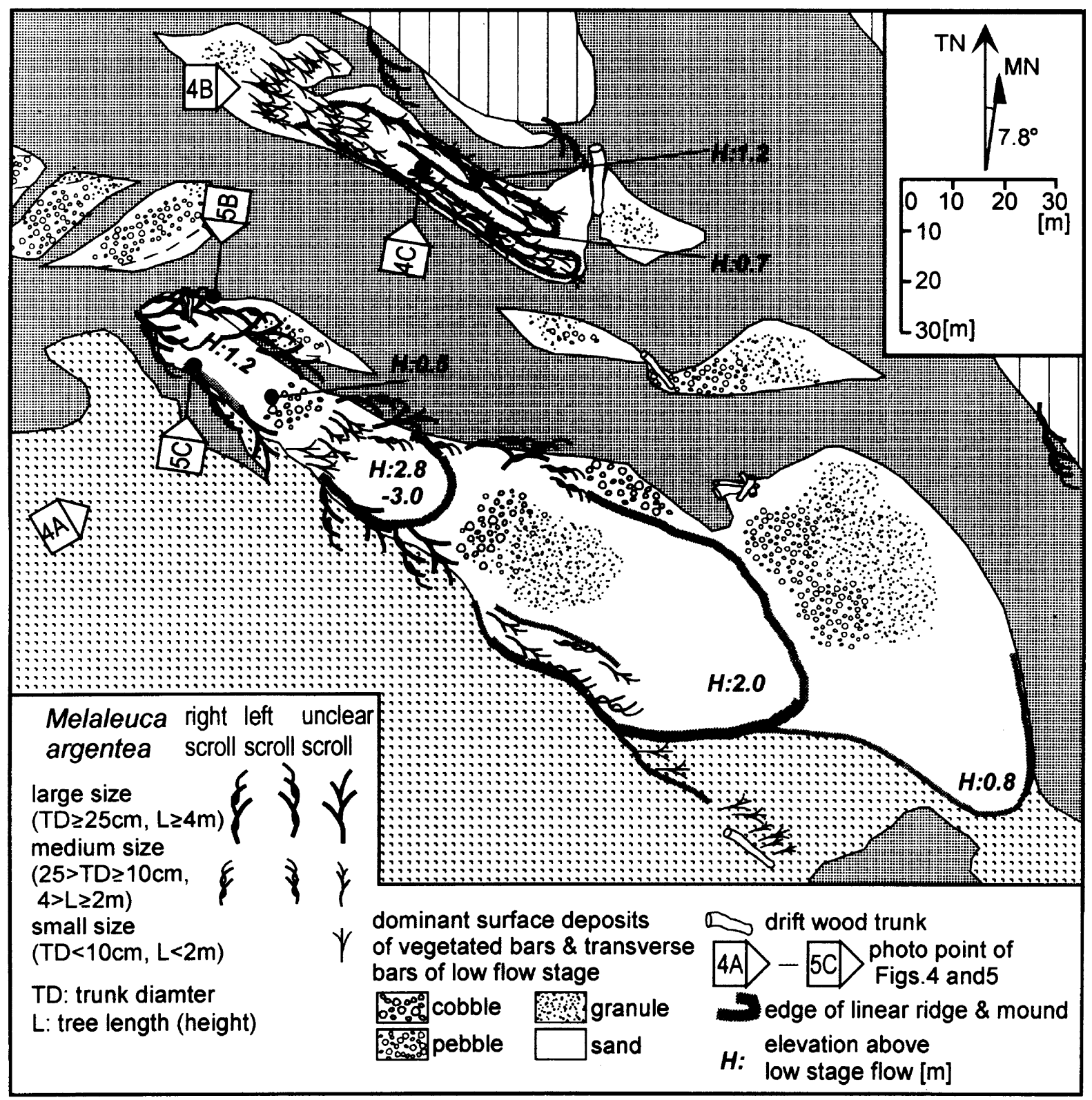

Figure 3. Vegetated transverse bars. Distribution and scroll direction of wood trunk and branching are precisely drawn. Number of trees (especially, saplings "small size" in legend) is generalized. Location is indicated in Figure 2.

Red Gum) and Lophostemon grandiflorus (Brush Box). A sharp break of slope and dense vegetation define the foot of the upper bar. Sediment of the upper bar surface varies between mud and medium sand. Gravels and very coarse sands occur locally on the surface. Obstacle marks are formed around mature trees at the lower margin of the upper bar.

Major high-stage flow can transport almost all sediments of the lower bar (Fielding et al., 1999). Such events have a return period of 3.5-8.5 years based on 100 years of hydrographic records. In the last de- cade, such events occurred in 1991, 1997, and 1998. However, mature $M$. argentea trees are common on the lower bar: some are $>30$ years old (Fielding et al., 1997), and must have survived several major highstage flow events.

In this article, we use three terms for flow condition on the basis of Fielding and Alexander (1996); bankfull flow (or high-discharge flow), intermediate flow, and low-stage flow. Bankfull flow is the once every few years flow which submerges the entire lower bar and most of the upper bar. Low-stage flow 
is the dry season flow that is restricted to the lower part of the lower bar. Intermediate (-stage) flow is quantitatively located between the above two flows, and is either due to intermediate levels of runoff, or the waning stage of bankfull flow.

\section{Obstacle marks}

Four types of obstacle marks are recognized on Dalrymple Bend. Two types are formed around in situ trees, one forms around grass clumps, and one is observed around stranded driftwood. A topographic distribution of each type is also recognized. These four types are described here in accordance with geomorphic location.

\subsection{Lower part of lower bar}

Obstacle marks are observed around in situ M. argentea trees and stranded driftwood. Obstacle marks typical of the lower part of the lower bar are common on the two vegetated bars at the Keelbottom Creek confluence (Figure 3). The larger southern bar has many mature trees that vary in size and shape, while the northern bar has only saplings. In this paper, the trees are categorized into three groups for convenience; mature trees more than $25 \mathrm{~cm}$ in diameter and $4 \mathrm{~m}$ long trunks, saplings less than $10 \mathrm{~cm}$ trunk diameter and $2.5 \mathrm{~m}$ long, and semi-mature trees with intermediate size between mature trees and saplings. Fielding et al. (1997) show the relationship between tree age and trunk circumference (at base of tree) in $M$. argentea in the study area. From this relationship, mature trees are more than 30 years old, and saplings less than 10 years old. Linear groves are typically organized so that mature trees are replaced by semimature trees and saplings in a down-flow direction (Figure 4A). However, groves of saplings are also present (Figure 4B \& 4C).

Several patterns of obstacle marks are recognized around $M$. argentea individuals and groves. Many saplings stand vertically, and align along flow direction. In 2000 saplings such as these had an obstacle scour $50-80 \mathrm{~cm}$ in diameter and $20 \mathrm{~cm}$ deep on their upstream side (Figure 4B). The sediment tail around each sapling is ambiguous in many cases because of the relatively dense vegetation. However, individual sediment tails merge downstream along such aligned groves to form distinct mounds, and ultimately linear sediment ridges up to $80 \mathrm{~cm}$ high. Within linear sediment ridges, saplings are aligned along the ridge crest (Figure 4C).

Obstacle marks around mature trees in linear groves are more complex. Mature trees are frequently succeeded by semi-mature trees and saplings in a downstream direction. Such linear groves are observable not only on the vegetated transverse bar but also in the bend entrance and exit areas of the lower bar (Figure 2). Mature trees in the fronts of the linear groves are inclined downstream by $15-40^{\circ}$. Trees elsewhere in the groves are also inclined. Many of them have the same inclination as the upstream-most trees, but others are less inclined and stand closer to vertical. Obstacle scour around the frontal inclined mature tree of each linear grove is superficially less than $10 \mathrm{~cm}$ deep in general. Some scours are covered with muddy sediments $3-5 \mathrm{~cm}$ thick, and the original erosional sours are deeper than the superficial morphology. However, even the original scours are not very deep (less than $80 \mathrm{~cm}$ ). Sediment tails around inclined mature trees are generally more than $2 \mathrm{~m}$ wide and $20 \mathrm{~m}$ long. The highest part of each tail is more than $30 \mathrm{~cm}$ thick. The sediment tail is composed mainly of cobble- to very coarse sand-sized particles associated with mud lenses. Fully mature trees show a spiral trunk and branching pattern. There is a relationship between the trunk spiral direction and the orientation of the sediment tail. Right spiral branching and trunk patterns in mature trees are associated with sediment tails on the right lee side of the trunk, while left spiral branching and trunk patterns are associated with tail development on the left lee side (Figure 5) (right and left described looking downstream).

Other obstacle marks in the lower part of the lower bar are observed around stranded driftwood. Most of the driftwood is ex-M. argentea, but eucalypt driftwood is also evident. The driftwood varies in size and shape up to more than $30 \mathrm{~m}$ long. Some are symmetrical because of the prior removal of branches and roots, while others such as entire trees or parts of trees are asymmetrical. Symmetrical elongate driftwood is generally stranded on the bar surface, with long axis direction transverse to the mean flow direction (Figure 6B), and asymmetrical driftwood is aligned with the mean flow direction (Figure 6A). Further, whole trees with roots are always stranded with roots facing upstream (Figure 6A) (cf. Alexan- 


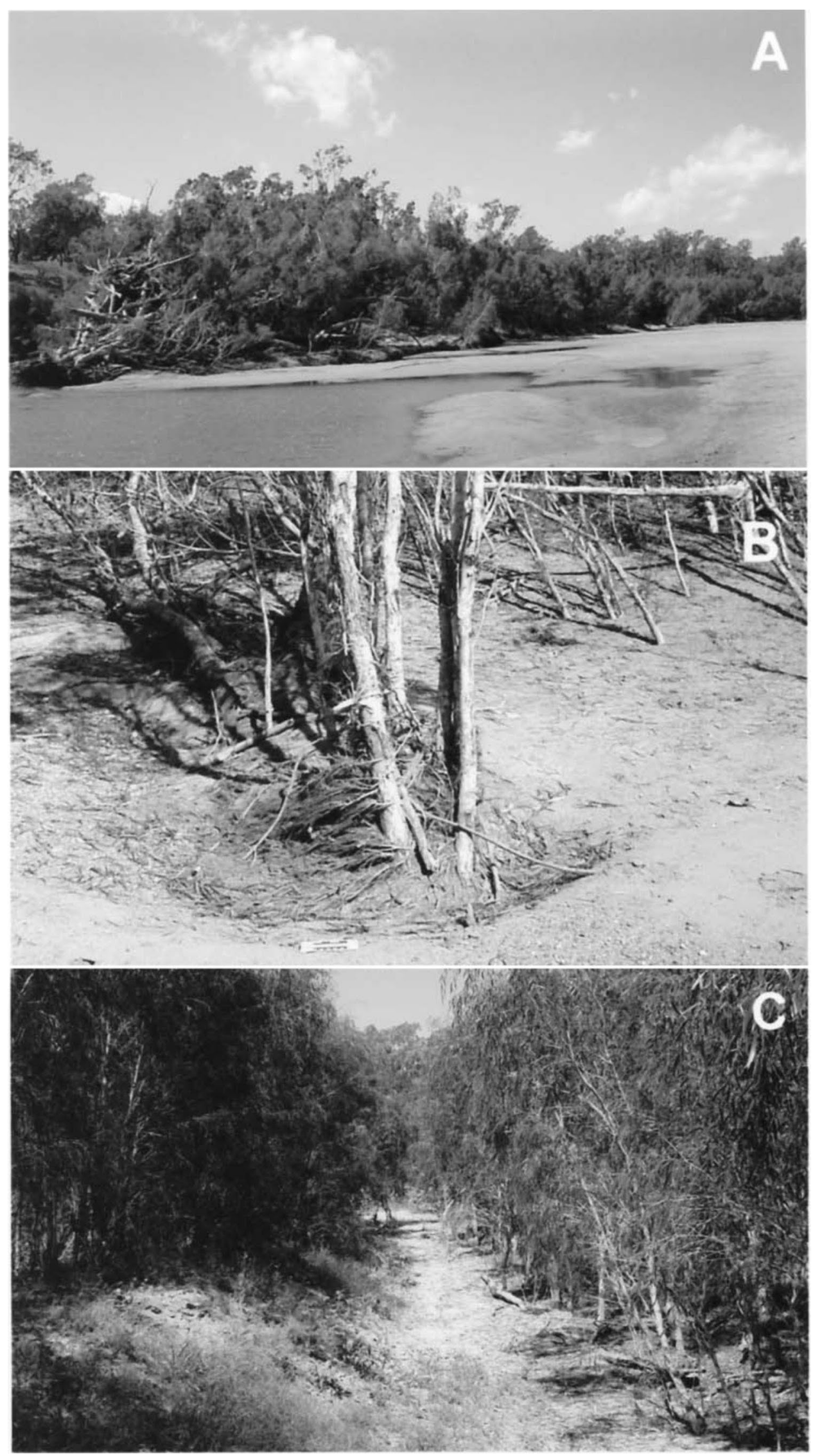

Figure 4. Photographs around vegetated transverse bars. All trees are $M$. argentea. Photograph sites are shown in Figure 3. (A) Whole view of the southern bar. Mature trees, semi-mature trees, and saplings are aligned along flow direction in groves. Mature trees are clearly reclined. Flow is from left to right. (B) Obstacle scour around saplings in the northern bar. Scale card is placed on the front side. Looking downstream. (C) Aligned saplings with mounded sediment tails in the northern bar. Looking downstream. 


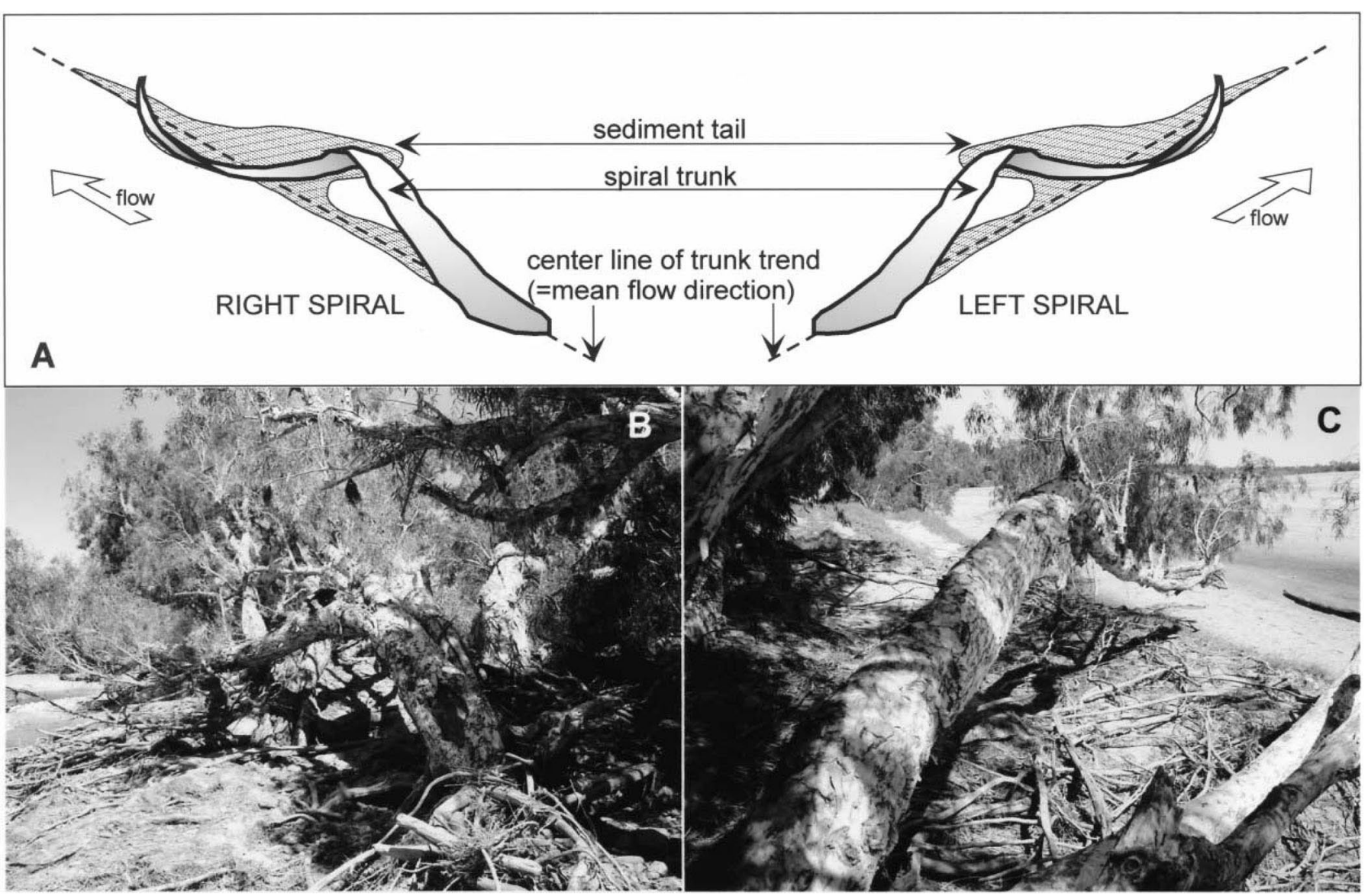

Figure 5. Cartoon and photographs of spiral pattern of M. argentea. Photograph sites are shown in Figure 3. (A) Cartoon indicates the relationship between the spiral pattern and the sediment tail. (B) Right spiral trunk on the left side of the southern bar in Figure 4. Looking downstream. (C) Left spiral trunk on the right side of the southern bar in Figure 4. Looking downstream.

der et al., 1999a). Obstacle marks, especially obstacle scours, around stranded driftwood are comparatively small relative to the size of driftwood. For example, a 30-m-long Eucalyptus obstacle with a 2.5-m diameter root crown observed in 2000 had a scour only $70 \mathrm{~cm}$ deep and $50 \mathrm{~cm}$ wide (Figure 6A).

\subsection{Upper part of lower bar}

Obstacle marks on the upper part of the lower bar are mainly observed around clumps of grass. The clumps are sporadically distributed with a density of 1-2 $\mathrm{m}^{-2}$, typically $10-30 \mathrm{~cm}$ in diameter (Figure 7). Three types of obstacle marks are recognized around grass clumps.

The first type consists of very small obstacle marks around grass clumps where all stalks are vertical. No sediment armoring is observed on such clumps. Scour in front of the obstacle is minimal (Figure 7A), although sandy sediment tails up to $1.0 \mathrm{~m}$ long are in all cases attached to the obstacle.

The second type is the most remarkable among the three types. Well-defined scours and sediment tails are formed around half-oval-shaped grass obsta- 

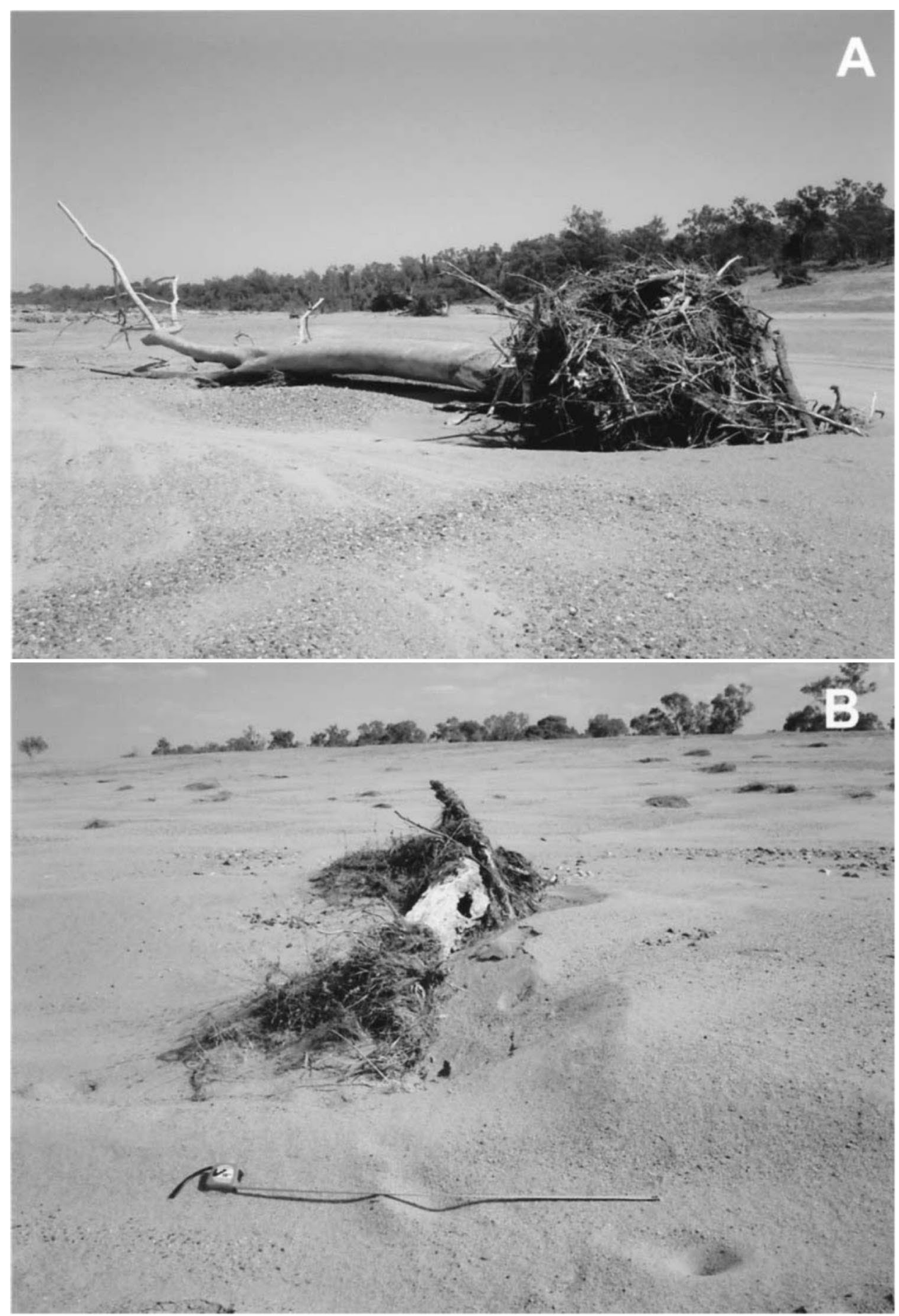

Figure 6. Stranded driftwood and associated obstacle mark. Photograph sites are shown in Figure 2. (A) Gum Tree (Eucalyptus) driftwood (30 m long), stranded parallel to flow, with comparatively small scour. Flow is from right to left. (B) M. argentea driftwood (3.0 m long) stranded normal to flow. Flow is from right to left. Scale is $1 \mathrm{~m}$. Higher elevation on right side is the front part of a dune bedform. Small scours with $3 \mathrm{~cm}$ depth and $1 \mathrm{~m}$ length are observed at the edges of the trunk.

cles (Figure 7C, 7D, \& 7E). All stalks are bent downstream, and obstacles are armored with mud, sand, and gravel. Armored obstacles are too hard to be dug by hand or small trowel. The armored part of this structure ranges between 15 and $30 \mathrm{~cm}$ high, and be- tween 20 and $35 \mathrm{~cm}$ long, and is elongate along the flow direction. Scours are 3-8 cm in depth, and sediment tails $0.7-5.0 \mathrm{~m}$ long. Some obstacles have two (or more) sandy and gravel sediment tails (Figure 7D). Multiple tailed obstacles always show that 


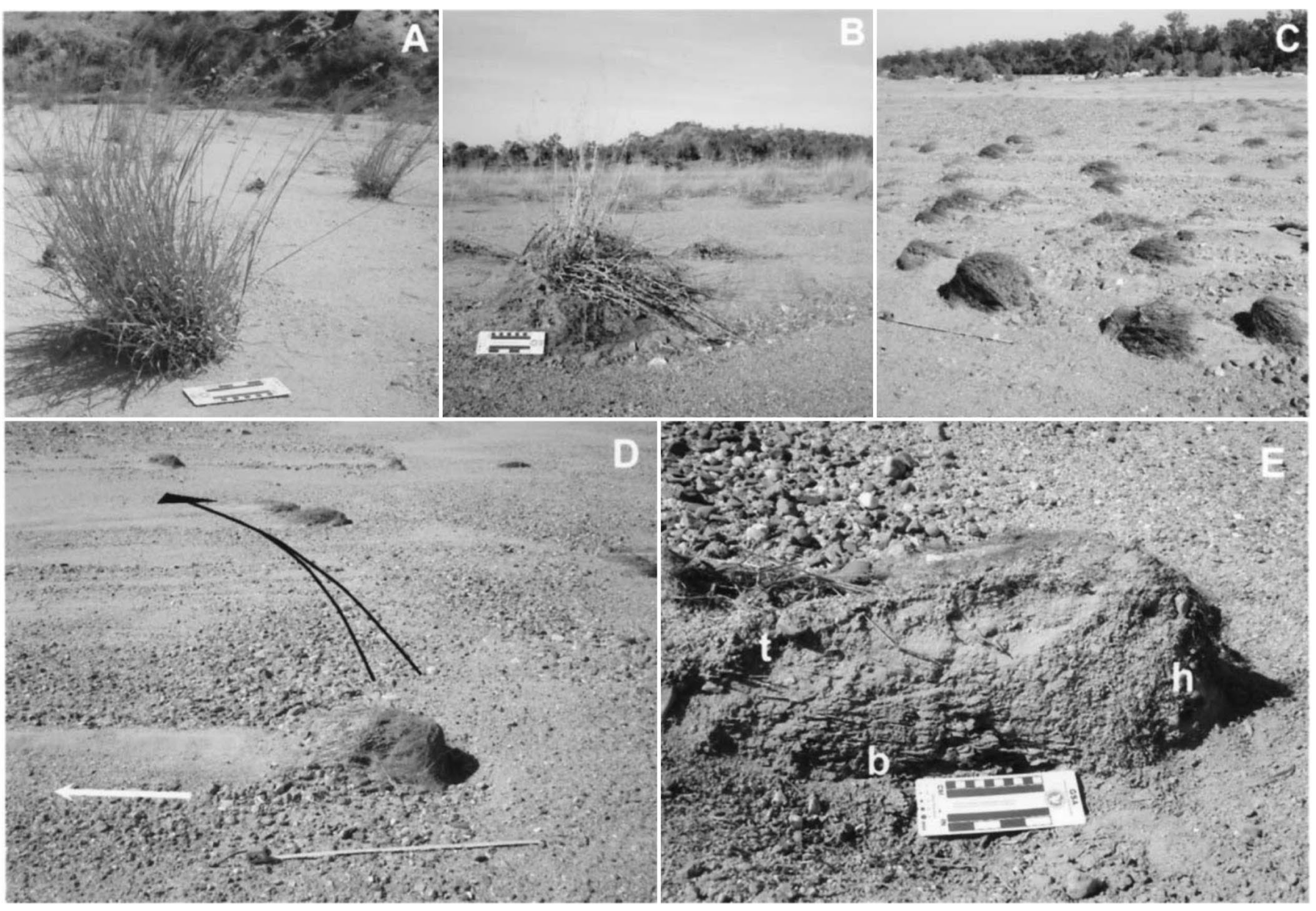

Figure 7. Obstacle marks around grass colonies. Photograph sites are shown in Figure 2. (A) A grass obstacle showing vertical stalks without sediment armoring has no scour at its base. Flow is from right to left. (B) A grass obstacle with both vertical stalks and downflow-inclined stalks, and is armored with muddy sediment at its base. Flow is from left to right. Sandy sediment tail and small scour are associated with this obstacle. (C) Grass obstacles armored with sediments form hard half-oval-shape obstacles. Scale is $1 \mathrm{~m}$. Flow is from left top to right bottom. (D) A half-oval-shape obstacle with a gravel sediment tail (black arrow) and sandy tail (white arrow). Sandy tail is overprinted on gravel tail. Black arrow is coincident with bankfull flow direction, while white arrow is coincident with local intermediate flow direction. Both directions are shown at the point of "7D" in Figure 2. Right bottom is upstream side. Scale is $1 \mathrm{~m}$. (E) Cross-section of a half-oval obstacle. " $\mathrm{h}$ " is the head part which is made of grass roots, mud, and gravel, " $b$ " is the bottom part of grass stalks, roots, and mud, " $\mathrm{t}$ " is the top part of grass stalks, sand, and mud. Flow is from right to left.

gravel tails are indistinct, and overlain by sandy distinct tail(s). Cobbles are common in gravel tails. The cross-section of an armored obstacle is shown in Figure 7E. The upstream one-third is grass fibril roots armored with mud and gravel (commonly matrix-supported in appearance) including cobbles (' $h$ ' in Figure 7E), the lower half of the other two-thirds is grass stalks and roots with mainly mud (' $b$ ' in Figure 7E), and the upper half is grass stalks with sand and mud (' $t$ ' in Figure 7E).

The third type of obstacle mark associated with grass is intermediate in character between the two types described above. The obstacle has both vertical and downflow-bent stalks, and is armored with mud, sand, and gravel (Figure 7B). Armored parts of this type range between 10 and $20 \mathrm{~cm}$ in diameter, which is generally smaller than the second type of halfoval-shaped grass obstacles. This type has an obstacle scour and tail, and is also smaller than those of the second type. This type does not form multiple sediment tails like some of the second type.

The spatial distribution of these three types is such that they are never found together. Each type occupies areas of more than $100 \mathrm{~m}^{2}$. There is no particular 


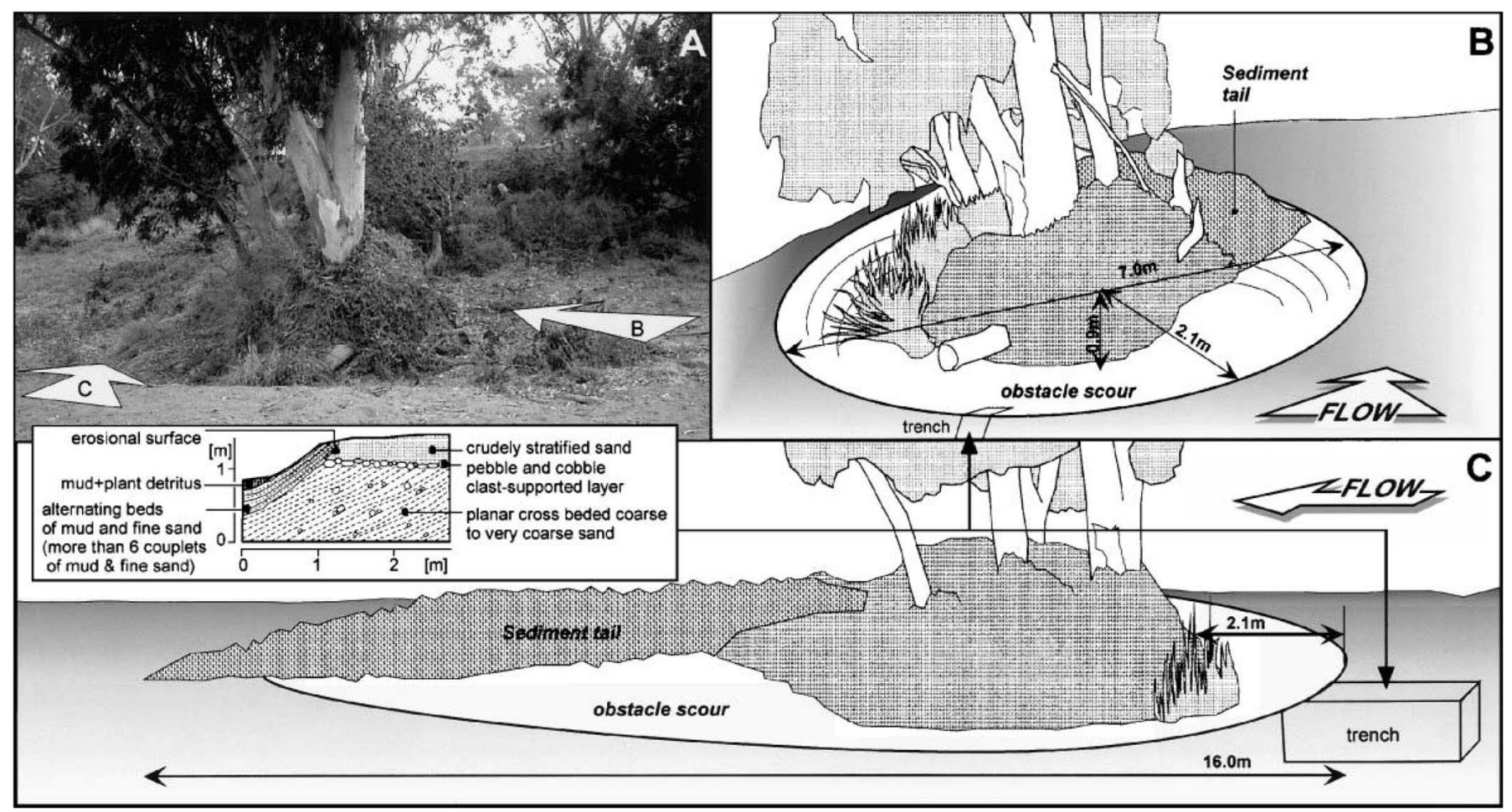

Figure 8. Obstacle marks around E. camaldulensis in the lower margin of the upper bar. (A) Photographs of the obstacle mark. B and $C$ arrows indicate the view direction of frontal view (B) and side view (C). B and C are sketches indicating the morphology. Obstacle scour is covered with alternating beds of mud and fine sand, such that the surface morphology does not precisely indicate the original scour size.

arrangement of the three types along the flow direction. However, the second type of half-oval-shaped obstacles is dominant around the bend entrance area where mud films are common on the bar surface.

On the upper part of the lower bar, obstacle marks around stranded driftwood are also present. Driftwood shows the two orientations similar to those described from the lower part of the lower bar. However, the number of driftwood fragments is substantially less than on the lower part of the lower bar, and driftwood there is generally smaller.

\subsection{Lower margin of upper bar}

Obstacle marks are rare on the upper bar, although several obstacle marks are observed at the lower margin of the upper bar, formed around mature trees. Two excellent examples were observed at the exit of the bend (" $8 \mathrm{~A}$ " in Figure 2) and in the middle part of the bend (120 m south from "7B" in Figure 2). The former is formed around E. camaldulensis, the latter around L. grandiflorus. Morphological and sedimen- tological features of these two are similar, regardless of tree species. Details of the E. camaldulensis example are shown in Figure 8 and described below.

The E. camaldulensis obstacle has four major trunks (max. $80 \mathrm{~cm}$ in diameter) emanating from the root crown $(3 \times 4 \mathrm{~m})$. The largest trunk is on the far upstream side of the tree. The scour pit is $2 \mathrm{~m}$ in radius on the frontal side, and $90 \mathrm{~cm}$ deep. On the lee side of the obstacle, there is a furrow $30 \mathrm{~cm}$ deep on the left side, and a mound $60 \mathrm{~cm}$ high and $9 \mathrm{~m}$ long. However, the original obstacle scour is a little larger, and the obstacle sediment tail slightly smaller, because excavation has revealed alternating beds of mud and fine sand 10 to $60 \mathrm{~cm}$ thick covering the original obstacle mark morphology. At least six couplets of sand and mud layers are recognized in the alternating beds. The original erosion scour is $2.3 \mathrm{~m}$ in radius on the frontal side, $130 \mathrm{~cm}$ in depth, and a gravelly sediment tail is 50 $\mathrm{cm}$ high and $9 \mathrm{~m}$ long. Scouring has eroded a cobble and pebble clast-supported layer (see cross-section in Figure 8). Similar features are recognized in the other obstacle mark around L. grandiflorus. 


\section{Forming processes of obstacle marks}

\subsection{Obstacle marks around M. argentea grove}

Obstacle marks around $M$. argentea trees vary according to the degree of development of the grove (Figure 9). At the study site, three stages of grove evolution are recognized; growth of sapling colonies and their alignment, trunk inclination of semi-mature trees, and trunk- or branch-spiral growth of semi-mature and mature trees.

During the first stage of sapling growth and their alignment into linear groves, obstacle scours that develop around saplings (Figure 4B) promote the entrainment of saplings into the flow. Obstacles always cause flow separation, so upstream margin saplings are particularly prone to scouring. Saplings that maintain vertical or high-angled trunks are similar to a vertical circular cylinder model. Scouring is initiated at the front and sides, because the obstacle causes a downward motion to the flow in front of the obstacle, and accelerates velocity on the flanks. On the other hand, flow speed is reduced in the lee of obstacles, and clasts that cannot be supported by the reduced flow power are deposited to form the sediment tail. Although the most upstream individuals of sapling groves have associated scours, more protected individuals downstream do not have apparent scours. Protected trees in such a depositional environment are not as readily entrained into the flow.

Sparsely distributed trees suffer strong scouring, and may be readily entrained into the flow, while densely distributed trees are protected against scouring because of the sediment tail of an the upstream adjacent tree. Scour-dominant environments are established among sparsely distributed trees, where trees are not located in the sediment tail of an upstream adjacent tree. Then more and more trees will be entrained into the flow. With time, the surviving saplings may form a linear grove, their stability assisted by amalgamation of multiple sediment tails (Figures 4 \& 9).

In the second evolutionary stage of grove development, many semi-mature trees are inclined downstream by $15-40^{\circ}$. The inclination is caused by flow shear of bankfull and intermediate flows. Obstacle marks in these groves are dominated by the sediment tails. Obstacle scouring is determined by the strength of deflected and separated flows caused by obstacles. Bed shear stress around the front and sides of an inclined trunk is substantially smaller than around a vertical trunk, because the downward flow along the inclined trunk will not be concentrated at the base of the trunk (i.e., the tree has reduced drag force when inclined). The lower the inclination angle of the tree trunk, the smaller the scouring effect at the frontal and side bases of the obstacle. However, there is still a large area of flow separation downstream from the trunk. Therefore, obstacle marks in these groves are the sediment tail-dominant type (Figure 9C).

The last evolutionary stage is the stage of spiral trunk and branch development. Once tree trunks are inclined during a bankfull discharge event, adventitious branch growth may be vertical from the trunk. In subsequent bankfull discharge events, mean flow direction is unlikely to be exactly aligned with the trunk so that the drag on the vertical branches imparts a torque to the tree and the trunk will become inclined to a slightly different direction. Spiral trunk must be formed by many recurrences of these processes. Obstacle marks are adapted to the spiral shaped obstacles, forming sediment tails slightly oblique to the flow direction. Obstacle scours are small, similar to the previous stage and for the same reason of trunk inclination. Sediment tails on right spiral branching or trunk trees are deposited to the right lee side of the tree, while sediment tails on left spiraling trees are to the left lee side. Flow is deflected by these trees, and reduced flow velocity is formed on one side of the lee. Vegetated stable bars can be formed if a right spiraling tree grove is attached to the left side of the bar, and a left spiraling grove is attached to the right side. The southern vegetated bar in Figure 3 is an excellent example of such a stable bar.

On Dalrymple Bend, these three types of groves and intermediate types are well represented. Obstacle marks around such groves show a continuous spectrum between scour-dominant types on saplings and oblique-attached sediment tail-dominant types on spiraling trees.

Fielding et al. (1997) described the alignment and inclination of $M$. argentea in terms of a survival strategy, and have suggested that such adaptation encourages the formation of stable bars. 

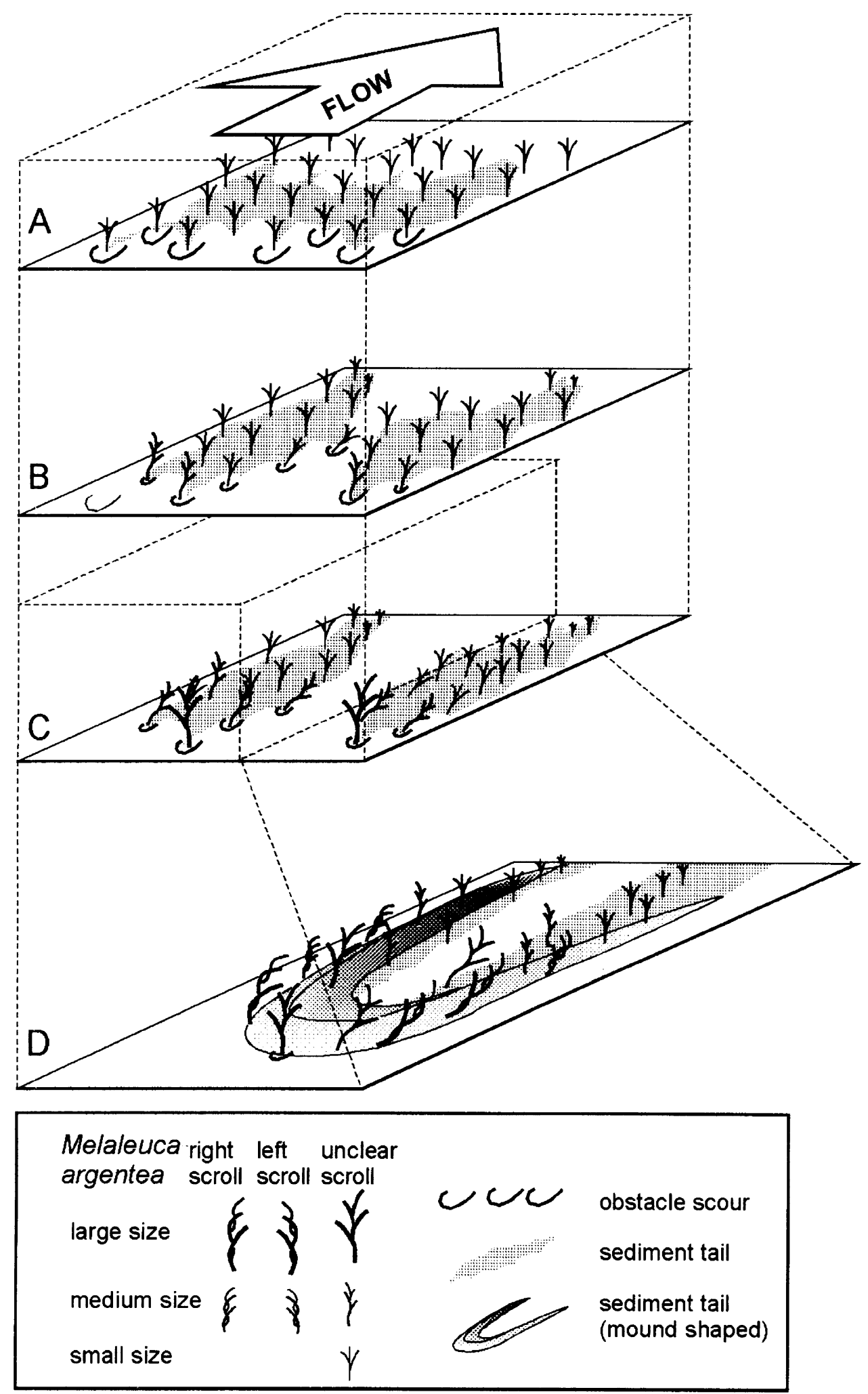

Figure 9. Formation model of obstacle marks around M. argentea. (A) Sapling colony. An apparent obstacle scour occurs around sapling, especially on the upstream margin of colony. (B) In sparse-distribution of saplings, some are entrained into flow by scouring erosion, forming aligned groves with mound configuration of sediment tails. (C) Trees are inclined by flow shear stress. Obstacle scour is substantially smaller around inclined tree. (D) Spiral growth of trunk and branches form sediment tails slightly oblique to flow direction. Right spiraling trees have tendency to attach the sediment tail to the right lee side of the tree trunks; left spiraling trees have tendency to attach the sediment tail to the left lee side of the tree trunks. 


\subsection{Obstacle marks around stranded driftwood}

Most driftwood fragments are derived from M. argentea, although others such as Eucalyptus are also recognized. Density of these woods is less than 1.0 $\mathrm{g} \mathrm{cm}^{-3}$. Driftwood may be stranded at edges of high stage flow or caught on obstacles (cf. Alexander et al., 1999a), but those particles forming obstacle marks on the bar surface must have been stranded in a flow, the depth of which is less than the length of the driftwood at least. During the bankfull or intermediate flow, wood fragments were observed to float near horizontally. This means that obstacle marks around stranded driftwood must be formed during waning flow stage of bankfull or intermediate flows. The relatively small size of the obstacle marks around driftwood supports this notion (Figure 10).

Asymmetrical whole trees with roots are always stranded with roots directed upstream. Drifting trees are thought to be stranded by roots catching on the bed initially, then the trunk is aligned parallel to the flow, using the first-stranded roots as an anchor. Obstacle marks, especially obstacle scours, can be formed just after stranding of the root. Some large branches with their largest part aligned parallel to flow will behave in a similar manner.

Symmetrical elongate driftwood is generally stranded with its long axis direction transverse to flow direction. Such driftwood indicates tractional (mainly rolling) movement on the surface. Obstacle marks must have formed after traction movement of driftwood has stopped but sediment is still mobile. This is most likely in very shallow flow.

\subsection{Obstacle marks around grass colonies}

There are three types of obstacle marks around grass colonies; very small marks around grass obstacles with all stalks vertical, obvious marks around half-oval-shaped grass obstacles armored with muddy sediments, and intermediate-sized obstacle marks around armored grass obstacles with both vertical and downflow-bent stalks.

The first type may have one of two origins; grasses germinated after the most recent bankfull or intermediate flow and the grass clumps have wind-induced small sandy sediment tails, or grass clumps have properties to prevent obvious obstacle marks from forming. On Dalrymple Bend in 2000, there were ju- venile grasses that germinated within a year, but they are uncommon. Such grass clumps are less than $3 \mathrm{~cm}$ in diameter. Most clumps have diameters of more than $10 \mathrm{~cm}$, and these must have grown before the last bankfull flow or intermediate flow events. Castro (1971) demonstrates the effect of obstacle porosity on obstacle marks, and indicates that obstacles with porosity more than 0.305 lose the capacity to deflect flow. The grass obstacles of the first type are non-armored and have a high porosity if the clump is regarded as one obstacle. Beside this, small sandy sediment tails around these non-armored obstacles are concordant with the river flow direction. Thus, the grass clumps without muddy armoring must have properties to prevent obstacle marks from forming. Small sandy sediment tails must be fluvial in origin not aeolian as the tail orientation is the same as the local water flow direction.

The second type is developed around a half-ovalshaped obstacle with muddy armoring. Cobbles were recorded in muddy sediments, with a mud matrix-supported appearance. Cobbles are significantly larger than the clasts on the surrounding bar surface. This suggests that the armoring progressed during several repetitions of the falling stage with mud suspension-fallout, and high-flow stage with cobble transport. Cobbles must have been "trapped" in unconsolidated muddy sediments. Some armored obstacles have two (or more) sediment tails comprising a well-shaped sandy tail and an indistinct-shaped gravel tail. The gravel tail is parallel to the bankfull flow trend, while the sandy tail is parallel to the local flow trend (e.g., 7D in Figure 2). These facts suggest that gravel tails are deposited during bankfull flow and sandy tails are formed during intermediate flow after bankfull flow.

Grass clumps seem to develop from the non-armored type to the completely armored half-oval type. The intermediate-sized type is transitional between non-armored and complete armored types. Gravel sediment tails are not observed around the intermediate-size type. The rigid part of this obstacle must be too small to trap the gravel sediment tail.

\subsection{Obstacle marks at the lower margin of upper bar}

Large-scale scours and gravelly sediment tails are noted around mature trees in the lower margin of the upper bar. Scouring eroded the cobble and 


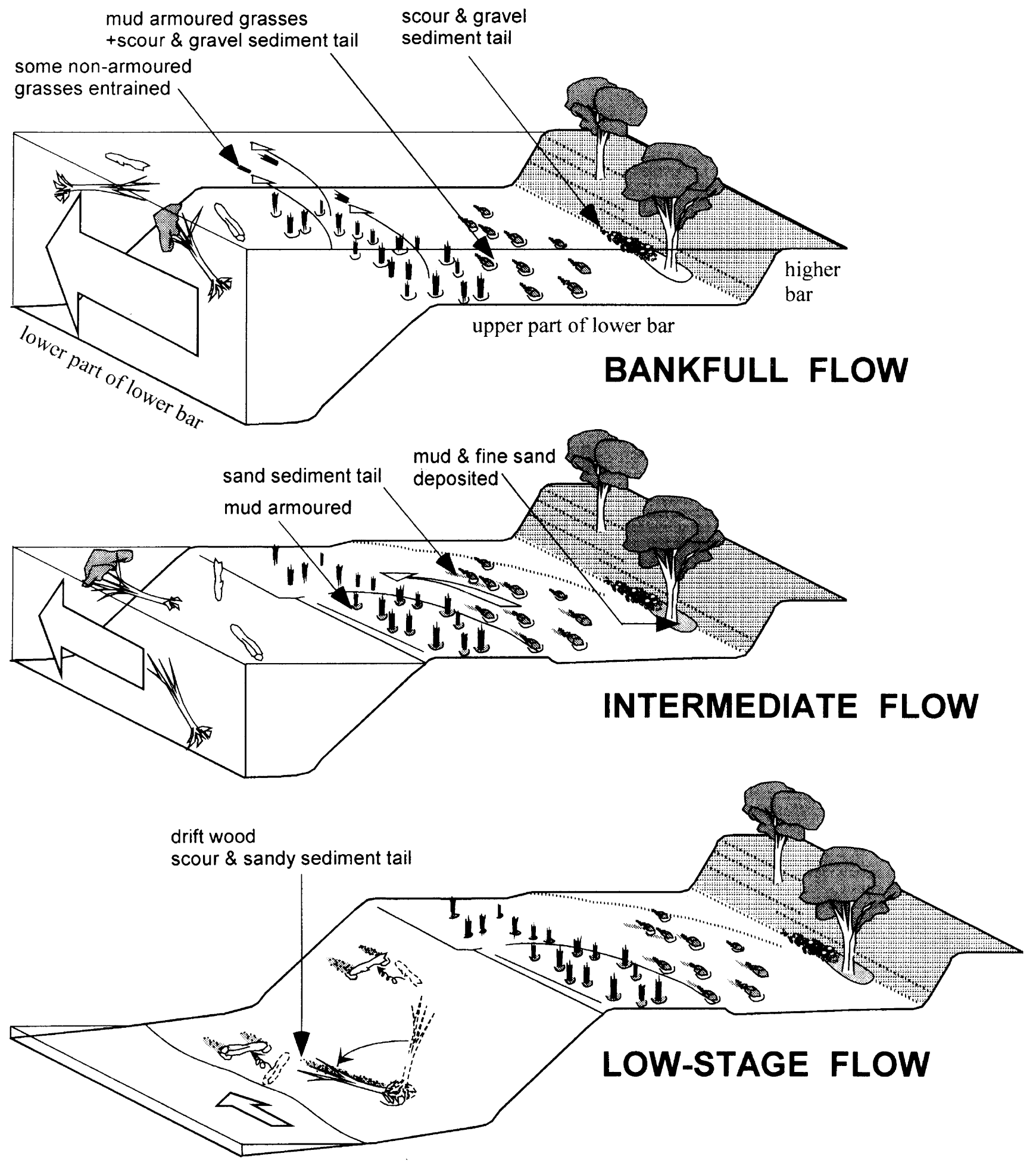

Figure 10. Forming processes of obstacle marks. Cartoon depicts the processes around a mature tree in the lower margin of the upper bar, grass colonies in the upper part of lower bar, and driftwood in the lower part of lower bar. White arrows indicate the flow direction. See text for details of formative processes.

pebble clast-supported layer, and the sediment tail contains many cobble clasts. Besides this, alternating beds of fine sand and mud cover both the scour and tail. The alternating beds are considered to have been formed by waning intermediate flows, because of their finer grain-size and blanketing distribution. 
Large velocity fluctuation in this intermediate flow would explain the grain-size difference between mud and fine sand beds. More than six couplets of mud and sand layers suggest that the alternating beds were formed by several flow events rather than a single event.

Although there are many mature trees on the upper bar, obstacle marks are very rare around these trees. The trees on the lower margin are exceptional in this respect. Dense grass vegetation on the upper bar must reduce the shear stress of flow, during bankfull or flooding stage, reducing scour around trees in addition to there being little sediment transport across, or deposition on this surface.

\section{Preservation potential of obstacle marks}

Long-term preservation of obstacle marks associated with trees in the modern Burdekin River implies that obstacle marks have a high potential for being preserved in the stratigraphic records in similar fluvial settings. The reworking of obstacle marks around grass clumps and especially driftwood suggest that preservation of these types of feature in the rock record would require unusual conditions, such as perhaps channel abandonment.

Obstacle marks around aligned groves of $M$. argentea have progressively modified their morphology, depending on the evolutionary stage. Some mature trees are more than 30 years old. This suggests that the morphology of obstacle marks and the obstacles themselves can remain for more than 30 years, although the morphology would vary during this period, and sediments of the obstacle mark may have been renewed by each bankfull or intermediate flow. So, the obstacle marks around $M$. argentea groves are thought to have a high preservation potential. Fielding et al. (1999) recognized hyperbola structures in the lower bar sediments on groundpenetrating radar (GPR) surveys, and interpreted these images as the record of buried trees. Such features probably record parts of $M$. argentea groves associated with obstacle marks (mainly sediment tails). In addition, observations in successive years have demonstrated that some high-stage events can bury groves of $M$. argentea, preserving sedimentary features formed around them.
Obstacle marks around stranded driftwood have a low potential to last more than 1 year (or one flood interval). The Burdekin River is subject to strong flows in most wet seasons. Most of the stranded driftwood will be entrained in the next bankfull (or intermediate) flow because of its low density $(<1 \mathrm{~g}$ $\mathrm{cm}^{-3}$ ). Peculiar stacking (or stranding) on the bar, may allow these structures to remain for more than 1 year. Some driftwood fragments are densely surrounded by small plant fragments. Surrounding material can act to reduce the bed shear stress in a similar way to the effect of dense grass vegetation on the upper bar. Such driftwood may survive during a few bankfull (or intermediate) flows. However, the preservation potential of such driftwood is still very low, because major high-stage flows, which have return periods of 3.5-8.5 years, can re-mobilize almost all the sediment and associated driftwood of the lower bar (Fielding et al., 1999). Linear groves of $M$. argentea in the lower bar represent exceptionally resilient obstacles.

Obstacle marks around grass clumps also have low potential for becoming a part of the stratigraphic record, for the same reason as stranded driftwood. However, obstacle marks around grass clumps are documented to remain more than 1 year. Existence of multiple sediment tails, especially gravel tails parallel to bankfull flow direction, is evidence of this. Obstacle marks around grass clumps are thought to exist more than 1 year and less than the recurrence period for major high-stage flow.

Obstacle marks in the lower margin of the upper bar must remain for a significantly long period, and have a high preservation potential. Firstly, these obstacle marks are covered with alternating beds of fine sand and mud. The mud layers are comparatively resistant to erosion. Secondly, observation of major high discharge events (with 3.5-8.5 years statistical recurrence) demonstrates that they cannot rework the majority of upper bar sediments (Fielding et al., 1999). Thirdly, obstacle trees are more than 10 years old based on their trunk size. These obstacle marks around mature trees on the lower margin of the upper bar must record the highest-stage flow that occurred during the life period of the tree, thus they are quite different from the progressively altered obstacle marks around the grove of M. argentea on the lower bar. 
The discussion of the potential for stratigraphic preservation suggests that two types of obstacle marks could be preserved fairly easily in the stratigraphic record; one is the obstacle marks around $M$. argentea linear groves, and the other is the obstacle marks around mature trees in the lower margin of the upper bar. These two types can be expected to be described from many ancient fluvial deposits (e.g., Fielding and Alexander, 2001), so the relation between these two types and hydrology is examined here. Obstacle marks around $M$. argentea groves are too complex to allow quantitative discussion, but obstacle marks around mature trees on the upper bar may allow such interpretation, although the flow character in this site on the bar may not be representative of the flow in the channel as a whole. Hence, such features preserved in the stratigraphic record have only limited value for interpretation of paleohydraulic conditions. The obstacle mark around $E$. camaldulensis illustrated in Figure 8 is used here as an example. At the trunk base and root crown, surrounding grasses, stems, and branches, form a buffer about $3 \mathrm{~m}$ wide. However, the furthest upstream wood trunk is $80 \mathrm{~cm}$ in diameter. A $80-\mathrm{cm}$-diameter cylinder shape is used here for estimation. Mean flow velocity of bankfull flow can be calculated by the formula of Shen et al. (1969), using obstacle size $(80 \mathrm{~cm})$, scour depth $(1.3 \mathrm{~m})$, and dynamic viscosity of water (supposing $15^{\circ} \mathrm{C}, 1.14 \times 10^{-6} \mathrm{~m}^{2} \mathrm{~s}^{-1}$ ). Estimated value is $1.73 \mathrm{~m} \mathrm{~s}^{-1}$. This value is substantially lower than the bankfull flow velocity of about $3.6-6.0 \mathrm{~m} \mathrm{~s}^{-1}$ estimated by Alexander et al. (1999b), using the floodwave speed and the relationship between bankfull flow and flood-wave of Knight and Shiono (1996). Supposing a highly sediment-laden flow, velocity value will be estimated as slightly higher because of the increment of viscosity. However, this re-estimated value is still low. Permeability of the obstacle, friction associated with the grass buffer around the Eucalyptus tree, and its position on the inside of the bend must play a role in reducing velocity at this site. Consequently, the estimated value may be close to the local flow velocity when the feature formed but not the open channel velocity at that time.

Although the data presented here are inadequate for quantitative discussion, they indicate three points for interpretation of the stratigraphic record. The first point is that some obstacle marks in the ac- tive channel (in settings with large discharge variability) have a high potential for being preserved in the stratigraphic record. An active channel is generally conducive to repeated reworking of the sediment of many obstacle marks in successive flow events. However, the morphology of obstacle marks around $M$. argentea trees have a high potential for a long preservation period and the same is likely to be true of other tree species evolved to cope with similar ecological niches. Therefore in the stratigraphic record, all trunks in coarse-grained channel bases are not necessarily channel lag deposits. The second point is that some obstacle scours are remarkably small despite forming during bankfull events. This has been deduced for example for many obstacle marks around M. argentea trees. These obstacle marks have well-defined tails but small scours, and are thought to be formed during the bankfull stages. Hence, small scours do not always reflect small discharge events. Furthermore, the obstacle marks around $M$. argentea trees imply that some upward-convex structures of coarse grains in channel deposits could be obstacle marks. The third point is related to the obstacle marks in the lower margin of the upper bar. These obstacle marks, being located in comparatively high elevation settings, have apparent scours eroding the major channel bedload of coarse sand and gravelly sand, and are covered by fine sand and mud. The scours must be formed during major bankfull flows. The grain size variation from mud to gravelly sand reflects the variable discharge. If similar obstacle marks are recognized in the stratigraphic record, they can support the interpretation of discharge variability, topographic position, and major bankfull flow-forming scour.

Obstacle marks described here can also provide one useful suggestion to civil engineers. The inclined and spiral trunk pattern of $M$. argentea formed a stable transverse bar in the active channel. The combination of linear obstacles with right spiral pattern and ones with left pattern can work for stabilizing a bar composed of multiple sediment tails.

\section{Conclusions}

Obstacle marks are described from Dalrymple Bend on the upper Burdekin River. The channel is di- 
vided into a sand- and gravel-covered lower bar and a densely vegetated upper bar. The lower bar is further subdivided into a lower part (0-3 $\mathrm{m}$ above the channel bottom) and an upper part (3-6 $\mathrm{m}$ above the channel bottom).

Two types of marks are observed in the lower part of the lower bar; sediment tail-dominated obstacle marks along inclined and linear groves of M. argentea trees, and small obstacle marks around stranded driftwood. On the former, sediment tails are deposited along inclined tree trunks, associated with minor frontal scour, which was formed during bankfull to intermediate flow. On the latter, symmetrical elongate driftwood is stranded transverse to the flow direction, and asymmetrical driftwood is aligned with the flow direction. Marks around driftwood are formed in waning conditions just before low-stage flow. Major obstacle marks in the upper part of the lower bar are formed around grass clumps armored with mud and gravels. Some armored clumps have both sandy and gravelly sediment tails, which indicates multiple stages of formation. At the lower margin of the upper bar, scours and gravelly sediment tails are recognized around mature trees. Scours are covered by alternating beds of fine sand and mud. Scours and gravelly sediment tails are formed during bankfull flow, and the covering alternating beds are formed during intermediate flow.

As for the preservation potential of obstacle marks, sediment tail-dominated obstacle marks around $M$. argentea have the highest potential. Scours and gravelly sediment tails in the lower margin of upper bar also have high potential. Obstacle marks around driftwood have the lowest potential for preservation. Obstacle marks around grass clumps do survive for more than 1 year, but their long-term preservation potential is low.

These modern obstacle marks suggest three important points for the interpretation of the stratigraphic record: (1) obstacle marks can be preserved in the lower part of an active coarse-grained alluvial channel, (2) scours around inclined trees are significantly small even if they are formed during bankfull stage, and (3) fine sediment covering obstacle marks around vertical mature trees reflects topographical high elevation, variable flow discharge, and major bankfull flow-forming scour.
Acknowledgments - We thank M. R. Gibling, R. A. Gastaldo, and A. D. Miall for their constructive reviews and comments on the manuscript. This study was partly supported by Japanese Ministry of Education (MEXT in present) Zaigai Research Program (KN), and the Australian Research Council (CRF: Grant code A39937196).

\section{References}

Alexander and Fielding, $1997 \bullet$ J. Alexander and C. R. Fielding, Gravel antidunes in the tropical Burdekin River, Queensland, Australia. Sedimentology 44 (1997), pp. 327-337.

Alexander et al., 1999a - J. Alexander, C. R. Fielding, and G. Jenkins, Plant-material deposition in the tropical Burdekin River, Australia: Implication for ancient fluvial sediments. Palaeogeogr., Palaeoclimatol., Palaeoecol. 153 (1999), pp. 105-125.

Alexander et al., 1999b • J. Alexander, C. R. Fielding, and G. D. Pocock, Flood behavior of the Burdekin River, tropical north Queensland, Australia. In: S. B. Marriott and J. Alexander, eds., Floodplains: Interdisciplinary Approaches - Geol. Soc. London Spec. Publ. vol. 163 (1999), pp. 27-40.

Allen, 1984 • J. R. L. Allen Sedimentary Structures, Elsevier, Amsterdam (1984) 593+663 pp.

Bhattacharya, 1992 - A. Bhattacharya, Current crescents formed by marine algae (Valonia sp.): A new record of obstacle marks lacking preservation of obstacles. Sedimentology 39 (1992), pp. 513-516.

Breusers, $1965 \bullet$ H. N. C. Breusers, Scour around drilling platforms. Bull. Int. Assoc. Hydraul. Res. 19 (1965), p. 276.

Burdekin Project Committee, 1977 • Burdekin Project Committee Resources and Potential of the Burdekin River Basin, Queensland, Australian Government Publishing Service, Canberra (1977) 195 pp.

Carstens and Sharma, 1975 • T. Carstens and H. R. Sharma, Local scour around large objects. Proc. Int. Assoc. Hydraul. Res. 18 (1975), pp. 251-262.

Castro, $1971 \bullet$ I. P. Castro, Wake characteristics of two-dimensional perforated plates normal to an air-stream. J. Fluid Mech. 46 (1971), pp. 599-609.

Dzulynski and Walton, $1965 \bullet$ S. Dzulynski and E. K. Walton, Sedimentary Features of Flysch and Graywackes, Elsevier, Amsterdam (1965) 274 pp.

Fielding and Alexander, 1996 • C. R. Fielding and J. Alexander, Sedimentology of the upper Burdekin River of north Queensland, Australia - An example of a tropical, variable discharge river. Terra Nova 8 (1996), pp. 447-457.

Fielding and Alexander, $2001 \bullet$ C. R. Fielding and J. Alexander, Fossil trees in ancient fluvial channel deposits: Evidence of seasonal and long-term climatic variability. Palaeogeogr., Palaeoclimatol., Palaeoecol. 170 (2001), pp. 59-80. 
Fielding et al., $1997 \bullet$ C. R. Fielding, J. Alexander, and E. Newman-Sutherland, Preservation of in situ, arboresent vegetation and fluvial bar construction in the Burdekin River of north Queensland, Australia. Palaeogeogr., Palaeoclimatol., Palaeoecol. 135 (1997), pp. 123-144.

Fielding et al., $1999 \bullet$ C. R. Fielding, J. Alexander, and R. McDonald, Sedimentary facies from ground-penetrating radar surveys of the modern, upper Burdekin River of north Queensland, Australia: Consequence of extreme discharge fluctuations. Int. Assoc. Sedimentol., Spec. Publ. 28 (1999), pp. 347-362.

Gibling et al., 1998 • M. R. Gibling, G. C. Nanson, and J. C. Maroulis, Anastomosing river sedimentation in the Channel Country of central Australia. Sedimentology 45 (1998), pp. 595-619.

Harwood and Brown, 1993 • K. Harwood and A. G. Brown, Fluvial processes in a forested anastomosing river: Flood partitioning and changing flow patterns. Earth Surf. Processes Landforms 18 (1993), pp. 741-748.

Jackson, 1976 - R. G. Jackson, II, Largescale ripples of the lower Wabash River. Sedimentology 23 (1976), pp. 593-623.

Jain, $1981 \bullet S$. C. Jain, Maximum clear-water scour around circular piers. J. Hydraul. Eng. 107 HY5 (1981), pp. 611-626.

Karcz, 1968 - I. Karcz, Fluviatile obstacle marks from the wadis of the Negev (southern Israel). J. Sediment. Petrol. 38 (1968), pp. 1000-1012.

Knight and Shiono, 1996 • D. W. Knight and K. Shiono, River channel and floodplain hydraulics. In: M. G. Anderson, D. W. Walling and P. D. Bates, eds., Floodplains Processes, Wiley, Chichester (1996), pp. 139-181.

Larras, 1963 • J. Larras, Profendeurs maximales d'érosion des fonds mobiles autour des piles en rivière (Maximum depth of erosion in shifting beds around river piles). Ann. des Ponts et Chausses 133 (1963), pp. 411-424.
Lim, 1997 • S. Y. Lim, Equilbrium clear-water scour around an abutment. J. Hydraul. Eng. 123 Hy3 (1997), pp. 237-243.

McKee et al., 1967 • E. D. McKee, E. J. Crosby, and H. L. Berryhill, Jr., Flood deposits, Bijou Creek, Colorado, June 1965. J. Sediment. Petrol. 37 (1967), pp. 829-851.

Melville and Dongol, 1992 • B. W. Melville and D. M. Dongol, Bridge pier scour with debris accumulation. J. Hydraul. Eng. 118 HY9 (1992), pp. 1306-1310.

Nakayama, 1992 • K. Nakayama, Fluvial gravel beds superimposed boulders in the Seto Group, central Japan. J. Sedimentol. Soc. Jpn. 37 (1992), pp. 79-84.

Nanson, $1981 \bullet$ G. C. Nanson, New evidence of scroll-bar formation on the Beatton River. Sedimentology 28 (1981), pp. 889-891.

Shen et al., $1969 \bullet$ H. W. Shen, V. R. Schneider, and S. Karaki, Local scour around bridge piers. J. Hydraul. Eng. 95 HY6 (1969), pp. 1919-1940.

Russell, 1993 • A. Russell, Obstacle marks produced by flow around stranded ice blocks during a glacier outburst flood (jökulhaup) in west Greenland. Sedimentology 40 (1993), pp. 1091-1111.

Wende and Nanson, 1998 • R. Wende and G. C. Nanson, Anabranching rivers: Ridge-form alluvial channels in tropical northern Australia. Geomorphology 22 (1998), pp. 205-224.

Woodyer et al., $1979 \bullet$ K. D. Woodyer, G. Taylor and K. A. W. Crook, Depositional processes along a very low-gradient, suspended-load stream: The Barwon River, New South Wales. Sediment. Geol. 22 (1979), pp. 97-120. 